\title{
IGF-1R Expression has More Potential Proliferation Effect in Invasive Breast Carcinoma Of No Special Type Compared to HER-2 Expression
}

\author{
Yessy Setiawati ${ }^{1}$, Aswiyanti Asri ${ }^{1}$, Rosfita Rasyid ${ }^{2}$ \\ yessyamri@gmail.com ${ }^{1}$, aswiyanti.asri@gmail.com ${ }^{1}$, rosfitarasyid135ros@gmail.com² \\ Department of Pathology Anatomic of Andalas University, Padang, Indonesia ${ }^{1}$ \\ Department of Public Health of Andalas University, Padang, Indonesia ${ }^{2}$
}

\begin{abstract}
About 75\% of breast carcinoma is invasive carcinoma of no special type (NST) and between $20 \%-30 \%$ of breast carcinoma is HER-2 positive. HER-2 overexpression now is a predictive factor for targeted therapy with anti-HER-2 agent like trastuzumab (herceptin). However, primary (de novo) resistance with trastuzumab occured in $65 \%$ patients and secondary resistance occured in $70 \%$ patients who have had good initial response. IGF-1R expression have been reported high in many malignancies including breast carcinoma. Researches have showed that IGF-1R signaling pathway have a crosstalk with HER-2 signaling pathway and was thought to become one of resistance mechanism in anti-HER-2 targeted therapy. This research was a retrospective observational cross-sectional study with a total 55 samples. Expression of IGF-1R and HER-2 was evaluated immunohistochemically. A strong positive IGF-1R cytoplasm and membranous expression was found in $18,2 \%$ and $34,5 \%$ cases, respectively. HER-2 expression was positive in $23,6 \%$ cases. IGF-1R cytoplasm expression was correlated significantly with mitosis count $(p=0.049)$. There was no correlation between IGF-1R membranous expression with mitosis count $(p=0,641)$. There was no correlation between IGF-1R membranous and cytoplasm expression with histological grade $(\mathrm{p}=1,000)$ and there was no correlation between HER-2 expression with mitosis count $(p=0,495)$ and histological grade $(p=1,000)$. IGF-1R expression has more potential effect in mitosis compared with HER-2 expression. Inhibition it's signaling pathway may have therapeutic value in breast carcinoma. Combination therapy of anti-HER-2 with anti-IGF-1R could overcome resistancy of trastuzumab in HER-2 positive breast carcinoma.
\end{abstract}

Keywords : Invasive breast carcinoma of NST, IGF-1R and HER-2 expression.

\section{Introduction}

Approximately 75\% breast carcinoma is invasive carcinoma of no special type (NST) (1). Breast carcinoma is heterogenous disease. Tumor with similar histologic subtype can have different clinical outcome and response to systemic therapy (2). Invasive carcinoma of NST have been reported to show highest heterogeneity among other subtype of breast carcinoma (3).

Breast carcinoma is the most common malignancy in woman all over the world (4). According to data from GLOBOCAN 2012, new cases of breast carcinoma was approximately 1,67 million (43 cases per 100,000 people) (5). A total of 48,998 breast carcinoma cases (40,3 
cases per 100,000 people) was reported in Indonesia. It was the third rank in the Ocean Pasific region after China and Japan (6). Data from Indonesian Association of Pathologist 2013 reported that a total 6,324 cases of breast carcinoma was diagnosed in all Center of Diagnostic of the Anatomic Pathology in Indonesia, and it was the most common diagnosed primary malignant lesion including in West Sumatera (7).

The mortality rates of breast carcinoma have been reported still high eventhough significant improvements in survival rates was reported. Breast carcinoma is the fifth cause of mortality in malignancy in the world (522,000 cases or 13 cases per 100,000 people) (5) (8). Resistance of targeted therapy is known as one of the cause of the high mortality rate in breast carcinoma. Based on expression of Estrogen Receptor (ER), Progesterone Receptor (PR), Human Epidermal Growth Factor Receptor-2 (HER-2) dan proliferation index of Ki-67, breast carcinoma is classified into 5 molecular subtype. Approximately 20\%-30\% of breast carcinoma is HER-2 positive (9) (10). HER-2 gene is located at chromosome $17 \mathrm{q}$ and have function to encode HER-2 protein, a transmembrane receptor family tyrosine kinase (11) (12) (13). Overexpression of HER-2 in breast carcinoma is correlated with aggressive behaviour, rapid progression, high grade tumor and higher number of recurrence and mortality rate. Overexpression of HER-2 is known as a predictive factor for targeted therapy with anti-HER-2 agents like trastuzumab (herceptin).

Many researches have reported that insulin-like growth factor type-1 receptor (IGF-1R) may have role in anti-HER-2 resistancy. IGF-1R expression have been reported high in many malignancies including breast carcinoma (17). IGF-1 ligand binds IGF-1R to initiate downstream signaling pathway of phosphatidylinositol 3-kinase (PI3K)-Akt which have role in cell survival and mitogen-activated protein kinase (MAPK) which have role in cell proliferation (18). These signaling pathway are also known initiated by HER-2 signaling pathway and was thought to become one of resistance mechanism in anti-HER-2 targeted therapy. There was no study about IGF-1R and HER-2 expression in breast carcinoma in Indonesia, especially in West Sumatera. Different ethnic and race is thought to have different role in pathogenesis of breast carcinoma in Indonesia. Study reported that not all breast carcinoma risk factors in the West are found in Minangese breast carcinoma (19). Therefore, this study was aimed to analyze expression of IGF-1R and HER-2 with histopathological factor of invasive carcinoma of no special type.

\section{Methods}

This research was a retrospective observational cross-sectional study. Samples were taken from Central Diagnostic of Pathology Anatomic of Andalas University Medicine Faculty and a total 55 samples fulfilled inclusion criterias from period 2014-2015. Samples were chosen using a simple random sampling method. IGF-1R and HER-2 expression was evaluated immunohistochemically from embedded paraffin blocks of invasive breast carcinoma of NST. IGF-1R expression was interpreted according to $h$-score system for cytoplasm staining and HER-2 scoring system for membranous staining. H-score calculated based on multiplying the products of the percentage of cells stained at a given staining intensity $(0-100)$ by the staining intensity score ( 0 , none; 1 , weak; 2 , moderate; and 3 , intense): $0-10$ points were considered to be negative, 11-100 points as weak, 101-200 points as moderate, and 201-300 points as strong positive. HER-2 expression interpreted based on American Society of Clinical Oncology/College of American Pathologists 2013 guideline as positif/3+, equivocal/2+ and negative $(1+/ 0)$. HER-2 strong positive/3+ defined as complete and circumferential membrane staining that is intense and within $>10 \%$ of the invasive tumor cells, HER-2 equivocal $/ 2+$ based 
on circumferential membrane staining that is incomplete and/or weak/moderate and within $>10 \%$ of the invasive tumor cells; or complete and circumferential membrane staining that is intense and within $\leq 10 \%$ of the invasive tumor cells, and HER-2 negative defined as weak or pale staining, incomplete $>10 \%$ of tumor cells (1+) or no staining (0). Samples were stained histologically with Hematoxyllin \& Eosin (H\&E) to determine mitosis count and histological grade. The correlation between IGF-1R and HER-2 expression with histopathological factors (mitosis count and histological grade) was analyzed using t-Test, Oneway Anova or Chi Square test. Only p-values $<0,05$ were considered as significant. All statistical analyses were performed using the SPSS statistical software version 17.0 (SPSS Inc., Chicago, USA)

\section{Results}

During period 2014-2015, there was 217 cases which have been diagnosed as invasive breast carcinoma of NST but only 55 cases fulfilled the criterias with mean age 48,89 $\pm 11,25$ year (range 28-69 year). The group of age between 50-59 year was the most frequently found invasive breast carcinoma of NST. Mitosis count in 10 HPF had median of 22 (range 4-51) (figure 1). High grade invasive breast carcinoma of NST was the most frequently found histological grade (figure 2). IGF-1R expression positive membranous staining was found in 19 cases $(34,5 \%)$ whereas positive cytoplasm staining 10 cases $(18,2 \%)$ (figure 3). HER-2 expression positive was found in 13 cases $(23,6 \%)$ (figure 4). Characteristics of patient is showed in table 1.

Statistical analysis found that there was no correlation between IGF-1R membranous staining with mitosis count $(\mathrm{p}=0,641)$ (Table 2) but there was a correlation between IGF-1R cytoplasm staining with mitosis count $(p=0,049)$ with Post hoc tests $p=0,049$ (Table 2, 3a and $3 \mathrm{~b})$. There was no correlation between IGFR-1R expression both of membranous and cytoplasm staining with histological grade, $\mathrm{p}=0,587$ and $\mathrm{p}=1,000$ respectively (Table 4 and 5). Also, there was no correlation between HER-2 expression with mitosis count and histological grade, $\mathrm{p}=0,495$ and $\mathrm{p}=1,000$ respectively (Table 6 and 7 ).

Table 1. Characteristics of patient (55 samples).

\begin{tabular}{|c|c|c|}
\hline Characteristics & & $\mathrm{n}(\%)$ \\
\hline \multicolumn{3}{|l|}{ Age (year) } \\
\hline - Mean & 48,89 (Median 50, SD 11,249) & \\
\hline - Range & $(28-69)$ & \\
\hline \multicolumn{3}{|l|}{ Age of group (year) } \\
\hline$-\quad<30$ & & $3(5,5)$ \\
\hline$-\quad 30-39$ & & $9(16,4)$ \\
\hline$-\quad 40-49$ & & $15(27,3)$ \\
\hline$-\quad 50-59$ & & $17(30,9)$ \\
\hline$-\quad>59$ & & $11(20,0)$ \\
\hline \multicolumn{3}{|c|}{ Mitosis count per $10 \mathrm{HPF}$} \\
\hline - Mean & 22,85 (Median 22, SD 10,952) & \\
\hline - Range & $(4-51)$ & \\
\hline \multicolumn{3}{|l|}{ Histological grade } \\
\hline - Low grade & & $23(41,8)$ \\
\hline - High grade & & $32(58,2)$ \\
\hline \multicolumn{3}{|l|}{ IGF-1R membranous } \\
\hline - Positive & & $19(34,5)$ \\
\hline
\end{tabular}




\begin{tabular}{clc}
\hline - & Negative & $36(65,5)$ \\
IGF-1R & cytoplasm & \\
- & Strong positive & $10(18,2)$ \\
- & Moderate & $9(16,4)$ \\
- & Negative & $36(65,5)$ \\
HER-2 & expression & \\
- & Positive & $13(23,6)$ \\
- & Equivocal & $8(14,5)$ \\
- & Negative & $34(61,8)$ \\
\hline
\end{tabular}

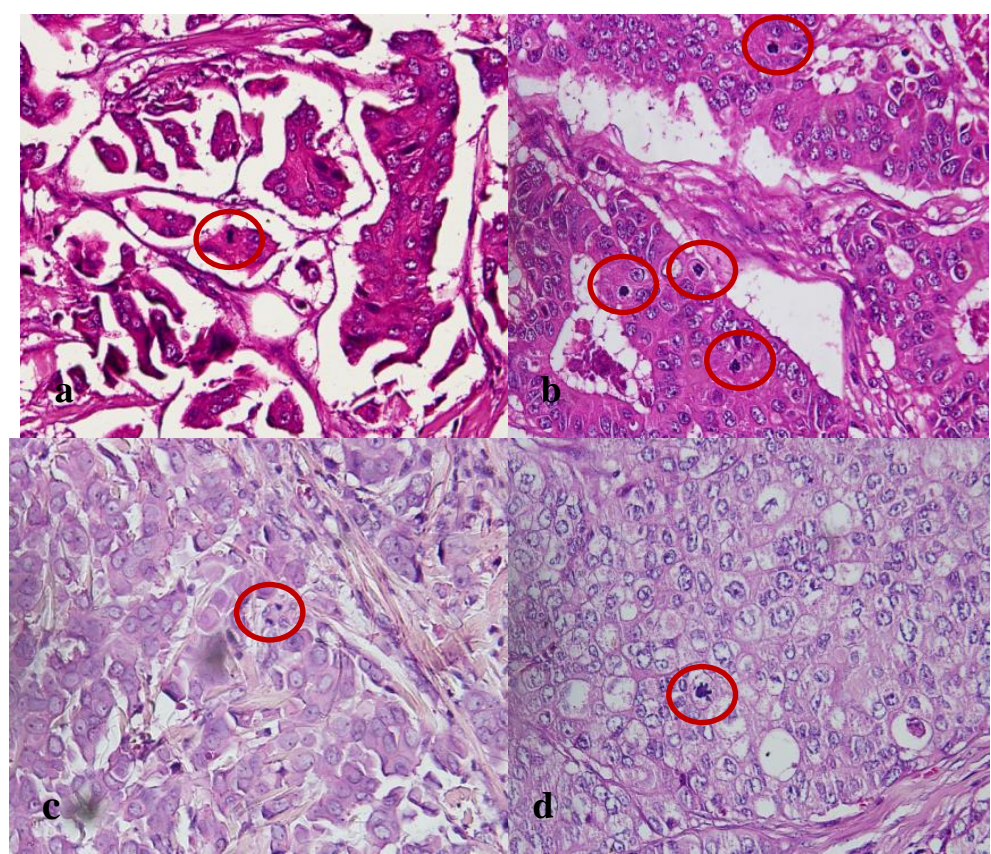

Figure 1 Mitosis images (a) at metaphase, (b) anaphase, (c) telophase, (d) atypical mitosis with multipolar nuclei chromatin (objective 40x).

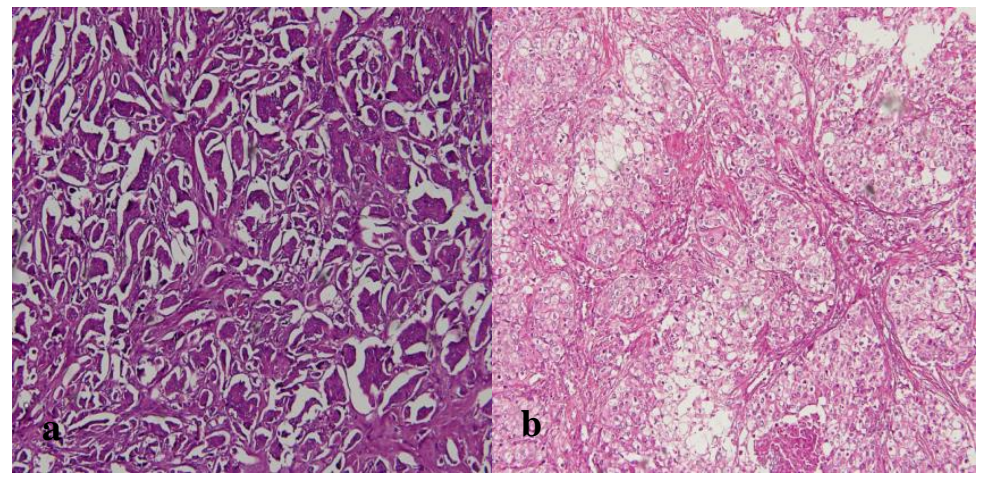


Figure 2 Histological grade invasive breast carcinoma of NST, (a) low grade (b) high grade (objective 20x).

Table 2 Correlation between IGF-1R membranous staining with mitosis count

\begin{tabular}{ccc}
\hline IGF-1R membranous & Mitosis count (mean \pm standard deviation) & p value \\
\hline Negative & $23,36 \pm 10,680$ & 0,641 \\
Positive & $21,89 \pm 11,685$ & \\
\hline
\end{tabular}

Table 3.a Correlation between IGF-1R cytoplasm staining with mitosis count

\begin{tabular}{lcc}
\hline IGF-1R cytoplasm & litosis count $($ mean \pm standard deviation $)$ & p value \\
\hline Negative & $23,36 \pm 10,680$ & 0,049 \\
Moderate & $28,22 \pm 10,733$ & \\
Strong positive & $16,20 \pm 9,727$ & \\
\hline
\end{tabular}

Table 3.b Post hoc test IGF-1R cytoplasm staining with mitosis count

\begin{tabular}{lccc}
\hline IGF-1R cytoplasm & Negative & Moderate & Strong positive \\
\hline Negative & - & 0,663 & 0,188 \\
Moderate & 0,663 & - & $\mathbf{0 , 0 4 9}$ \\
Strong positive & 0,188 & $\mathbf{0 , 0 4 9}$ & - \\
\hline
\end{tabular}

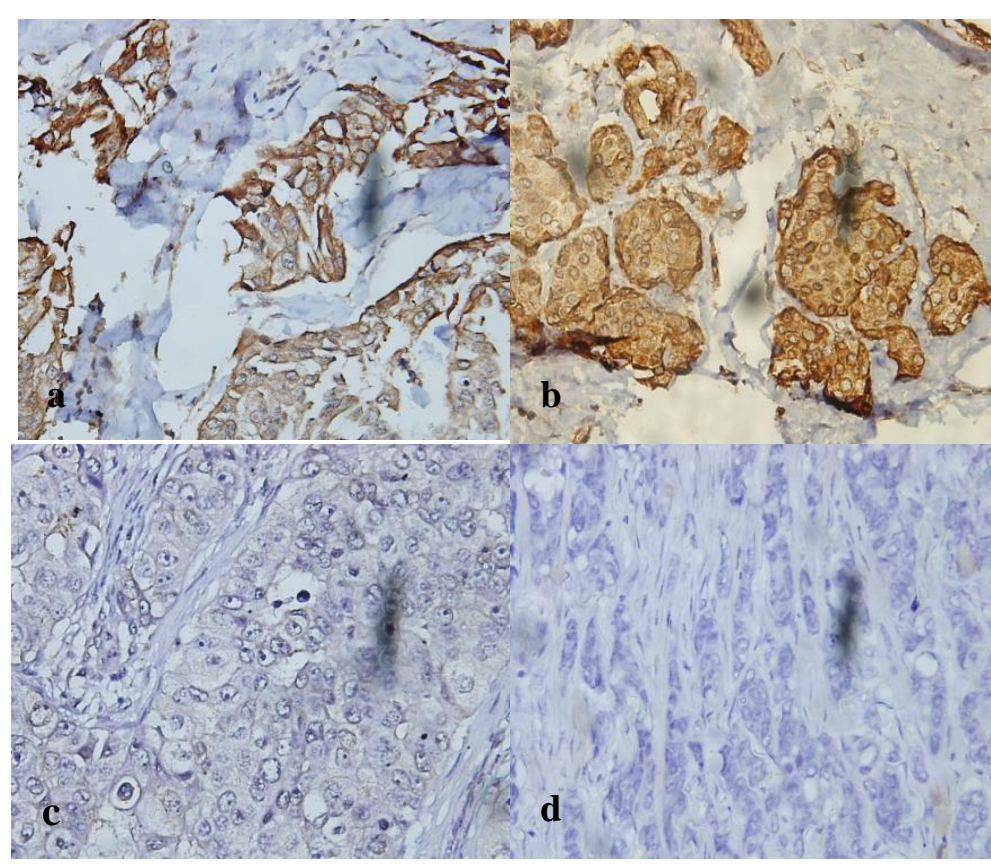

Figure 3 IGF-1R expression, (a) membranous staining moderate incomplete $\leq 10 \%$ of tumor cells (+2/positif), (b) cytoplasm staining strong positive (h-score 201-300) (c) pale staining, incomplete $>10 \%$ of tumor cells (+1/negative) (d) no staining (negative/0) (objective $40 x)$. 
Table 4 Correlation between IGF-1R membranous staining with histological grade

\begin{tabular}{|c|c|c|c|c|c|c|c|}
\hline \multirow{3}{*}{$\begin{array}{l}\text { IGF-1R } \\
\text { membranous }\end{array}$} & \multicolumn{4}{|c|}{ Histological grade } & \multicolumn{2}{|c|}{ Total } & \multirow[t]{3}{*}{ p value } \\
\hline & \multicolumn{2}{|c|}{ Low grade } & \multicolumn{2}{|c|}{ High grade } & & & \\
\hline & $\mathrm{F}$ & $\%$ & $\mathrm{~F}$ & $\%$ & $\mathrm{~F}$ & $\%$ & \\
\hline Negative & 16 & 44,4 & 20 & 55,6 & 36 & 100 & \\
\hline Positive & 7 & 36,8 & 12 & 63,2 & 19 & 100 & 0,587 \\
\hline
\end{tabular}

Table 5 Correlation between IGF-1R cytoplasm staining with histological grade

\begin{tabular}{|c|c|c|c|c|c|c|c|}
\hline \multirow[t]{3}{*}{ IGF-1R cytoplasm } & \multicolumn{4}{|c|}{ Histological grade } & \multirow{2}{*}{\multicolumn{2}{|c|}{ Total }} & \multirow[t]{3}{*}{ p value } \\
\hline & \multicolumn{2}{|c|}{ Low grade } & \multicolumn{2}{|c|}{ High grade } & & & \\
\hline & $\mathrm{F}$ & $\%$ & $\mathrm{~F}$ & $\%$ & $\mathrm{~F}$ & $\%$ & \\
\hline Negative & 16 & 44,4 & 20 & 55,6 & 36 & 100 & \\
\hline Moderate & 2 & 22,2 & 7 & 77,8 & 9 & 100 & 1,000 \\
\hline Strong positive & 5 & 50,0 & 5 & 50,0 & 10 & 100 & \\
\hline
\end{tabular}

Table 6 Correlation between HER-2 expression with mitosis count

\begin{tabular}{lcc}
\hline HER-2 expression & $\begin{array}{c}\text { Mitosis count (mean } \pm \text { standard } \\
\text { deviation) }\end{array}$ & p value \\
\hline Negative & $24,18 \pm 12,197$ & 0,495 \\
Equivocal & $21,88 \pm 10,829$ & \\
Positive & $20,00 \pm 6,916$ & \\
\hline
\end{tabular}

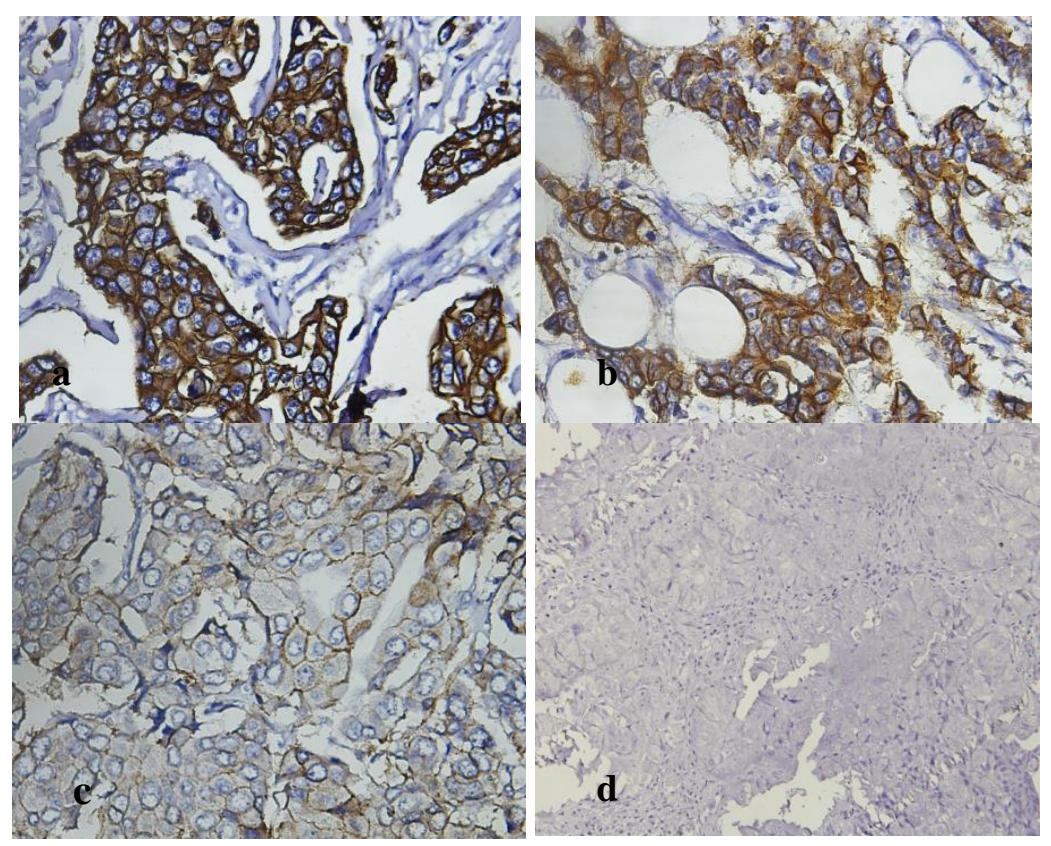

Figure 4 HER-2 expression, (a) strong staining, complete/circumferential $>10 \%$ of tumor cells ( $+3 /$ positive), (b) moderate staining, incomplete $>10 \%$ of tumor cells $(+2 /$ equivocal) (c) pale 
staining, incomplete $>10 \%$ of tumor cells $(+1 /$ negative) $(d)$ no staining (negative/ 0 ) (objective 40x).

Table 7 Correlation between HER-2 expression with histological grade

\begin{tabular}{lllllllll}
\hline \multirow{2}{*}{ HER-2 expression } & \multicolumn{4}{c}{ Histological grade } & \multicolumn{2}{c}{ Total } & \multirow{2}{*}{ p value } \\
\cline { 2 - 5 } & \multicolumn{3}{c}{ Low grade } & \multicolumn{2}{c}{ High grade } & & & \\
& \multicolumn{1}{c}{ F } & $\%$ & F & $\%$ & F & $\%$ & \\
\hline Negative & 15 & 44,1 & 19 & 55,9 & 34 & 100 & \\
Equivocal & 2 & 25,0 & 6 & 75,0 & 8 & 100 & 1,000 \\
Positive & 6 & 46,2 & 7 & 53,8 & 13 & 100 & \\
\hline
\end{tabular}

\section{Discussions}

Mean age of invasive breast carcinoma of NST in this study was similar to other studies in Indonesia. Khambri (2015) reported that mean age of breast carcinoma patients in West Sumatera was 48,59, Tinambunan et al (2013) found it was 47,9 in Palembang, Kosasih and Artha (2011) found it was 47,57 in Denpasar (20) (21) (22). Meanwhile, Ng et al (2011) study which compared clinicopathological characterictics between Indonesian and Malaysian breast carcinoma reported that mean age of patients was 47 in Indonesia (23). From literatures we have already known that mean age of breast carcinoma in Asian countries including Indonesia is lower than in the Western countries. This circumstance can be explained by the structure of the population pyramid which mainly consist of young population. Other, it can also be explained by the difference of age-spesific incidence pattern between Asian and Western. In Asian, there was a flat age-incidence curve after menopause (4) (23).

In this study, invasive breast carcinoma of NST was frequently found between age 50-59 year (30,9\%). It was different from many studies that have been reported in Indonesia and Asia. According to Hutagalung et al (2014), Kosasih and Artha (2011) in Denpasar, breast carcinomas was frequently found between 41-50 year (22) (24). The similar found was reported by Tinambunan et al (2013) in Palembang and also Khambri (2015) in West Sumatera (21) (20). In Asia, Mousavi et al (2006) in Tehran and Yip et al (2006) in Malaysia found that it was between age of 40-49 (25) (26). However, a study from Kamarlis (2017) in Medan Indonesia reported that basal-like subtype breast carcinoma was frequently found between age 50-59 year (27). Also, Devi et al (2012) in Malaysia have reported that breast carcinoma in Chinese ethnic of Southeast Asia was frequently found between age 50-59 year (28). From all those studies we concluded that different molecular subtype, also ethic/race was related with age of group of breast carcinoma.

More than half of invasive breast carcinoma of NST was high grade $(58,2 \%)$. Result from this study similar with other studies that have been reported in Indonesia. Aryondono et al (2006), Tinambunan et al (2013), Hutagalung et al (2014), Jatiluhur et al (2014), Kadi and Hoesin (2014) also Nelson et al (2014) reported that high grade breast carcinoma was more frequently found than low grade (21) (24) (29) (30) (31) (32). However, widodo et al (2014) in Yogyakarta and Aini et al (2015) in Semarang reported that invasive breast carcinoma of NST grade 2 (low grade) was the most frequently found histological grade (33) (34).

The high number of high grade breast carcinoma was found in Indonesia probably due to late-stage diagnoses. Reason for the late stage diagnoses was patient's delay to search medical help. Factors have known to contribute for the delay including culture and belief in most of 
Asian and Indonesian which seek for traditional medication first to treat their disease, reluctance or refusal to have one's breasts examined by a male doctor, woman should ask family or husband's permission for every decision she made and lack access to health care facilities particularly in suburban district due to lower income (8) (23). In Indonesia, many reports found that most of breast carcinoma patients came to the hospital at late stage of clinical desease. Data from Division of Oncology Surgery Department of Dr. M. Djamil National Hospital registry in Padang, West Sumatera showed that in 2013 a total $77,2 \%$ breast carcinoma patients came to the hospital at late stage (IIIB and IV) (19) (20). Widodo et al (2014) also reported that 54,8\% breast carcinoma patients who came to Sardjito National Hospital in Yogyakarta was at stage III (33). Jatiluhur et al (2014) reported 50\% breast carcinoma patients who came to National Hospital of Dr. Hasan Sadikin Bandung was at late stage (30).

IGF-1R expression in other researches have a wide range of value. Shin et al (2014) reported only IGF-1R positive membranous expression which they found as much as $65,4 \%$ (17). Yerushalmi et al (2012) also reported IGF-1R positive membranous expression in total $46 \%$ cases (35). Both of them didn't report any cytoplasm expression. In this study, IGF-1R expression was reported as membranous and cytoplasm staining. A total 19 cases $(34,5 \%)$ invasive breast carcinoma of NST have IGF-1R expression moderate positive membranous staining. In this study, we didn't find a strong positive membranous staining of IGF-1R expression according to HER-2 scoring system that most of studies adopted. Meanwhile, IGF$1 \mathrm{R}$ cytoplasm expression was found moderate in 9 cases $(16,4 \%)$ and strong positive in 10 cases $(18,2 \%)$ according to $h$-score system. This study was similar to Fu et al (2011) who also reported IGF-1R membranous and cytoplasm expression. They found a strong positive membranous and cytoplasm of IGF-1R expression in 3\% and 9\% cases respectively (36). Before that, Köstler et al (2006) reported similar found of IGF-1R expression. They reported a strong positive membranous and cytoplasm of IGF-1R expression in $14 \%$ and $8 \%$ cases respectively (37).

Although IGF-1R expression is frequently found in breast carcinoma, there is no a valid immunohistochemically guidelines universally with respect to both intensity and pattern of the IGF-1R staining. Most of studies referred to HER-2 scoring guidelines system from DAKO but in this study we can't only use HER-2 scoring system as we found cytoplasm expression was more visible than membranous expression. According to Fu et al (2011) and Köstler et al (2006), as IGF-1R is a transmembrane tyrosine kinase, it is reasonable to find a membranous staining. For the cytoplasm expression, there was two explanations that should be taken into consideration. First, the antibody that is used in this study detected the $\beta$ subunit of IGF-1R which is located on the internal side of the membranous. Second, although IGF-1R represents as membrane-bound tyrosine kinase receptor, the IGF-1R is translocated from the cell membranous to the cytosol with cytoplasmic IGF-1R representing a bound, internalized and thus a potentially activated receptor. Alternately, predominant cytoplasm staining may represent a failure to translocate IGF-1R to the surface (36) (37).

HER-2 positive expression was found in 13 cases $(23,6 \%)$. This finding was concordant with other findings that had established. Studies found that HER-2 overexpression is reported between 20\%-30\% breast carcinoma (9) (10). Some studies reported that it is between $15 \%$ $20 \%$ breast carcinoma (13) (38).

We found that there was a significant correlation between IGF-1R cytoplasm expression with mitosis count $(\mathrm{p}=0,049)$ but there was no correlation between IGF-1R membranous expression with mitosis count $(\mathrm{p}=0,641)$. As we have explained before, IGF-1R cytoplasm expression was more visible than membranous and thought have more potential effect. From literatures, IGF-1R signaling pathway was mainly iniatiated PI3K/Akt signaling pathway. Activated this molecular signaling pathway increased mitogenesis, cell cycle progression and 
apoptosis inhibition (39). There was no correlation between IGF-1R expression both cytoplasm and membranous with histological grade and also we didn't find correlation between HER-2 expression with mitosis count and histological grade. We assumed that there is another molecular pathway that involve in pathogenesis of invasive breast carcinoma of NST in this recent study. In this study, we found that more than a half of invasive breast carcinoma of NST was high grade. From literatures, group of high grade breast carcinoma are HER-2 positive and basal-like subtype. Basal-like subtype is a group of breast carcinoma which have ER, PR and HER-2 negative expression also known as triple negative breast carcinoma (TNBC) (40). We suspect that in this study there was a chance that high grade breast carcinoma was basal-like subtype. The similar finding was reported by Köstler et al (2006) who also found that there was no correlation between IGF-1R and HER-2 with histopathological factors in breast carcinoma that was assumed as a group of basal-like subtype (37).

\section{Conclusions}

We concluded that IGF-1R expression has more potential effect in mitosis. Inhibition it's signaling pathway may have therapeutic value in breast carcinoma. Combination therapy of anti-HER-2 with anti-IGF-1R may overcome resistancy of anti-HER-2 agent in breast carcinoma HER-2 positive.

\section{References}

(1) Hoda, SA. Invasive Ductal Carcinoma: Assessment of Prognosis with Morphologic and Biologic Markers. In (Hoda SA, Brogi E, Koerner FC, Rosen PP, eds) Rosen's Breast Pathology, $4^{\text {th }}$ ed. Philadelphia: Wolters Kluwer, pp. 413-67 (2014).

(2) Viale, G. The Current State of Breast Cancer Classification: Symposium Article. Ann Oncol, Vol. 23, Supplement 10, pp. x207-10 (2012).

(3) Strumfa, I. Vanags, A. Abolins, A. Gardovskis, J. Pathology of Breast Cancer: from Classic Concepts to Molecular Pathology and Pathogenesis. Acta Chirurgica Latviensis, Vol. 12, No. 1, pp. 59-66 (2012).

(4) Ferlay, J. Héry, C. Autier, P. Sankaranarayanan, R. Global Burden of Breast Cancer. In (Li CI, ed) Breast Cancer Epidemiology. New York: Springer Science+Business Media, pp. 1-19 (2010).

(5) Ferlay, J. Soerjomataram, I. Dikshit, R. Eser, S. Mathers, C. Rebelo, M. et al. Cancer Incidence and Mortality Worldwide: Sources, Methods and Major Patterns in GLOBOCAN 2012. Int J Cancer, Vol. 136, No. 5, pp. 359-86 (2015).

(6) Youlden, DR. Cramb, SM. Yip, CH. Baade, PD. Incidence and Mortality of Female Breast Cancer in The Asia Pacific Region. Cancer Biology and Medicine, Vol. 11, No. 2, pp. 101-15 (2014).

(7) Badan Registrasi Kanker Perhimpunan Dokter Spesialis Patologi Indonesia. Kanker di Indonesia Tahun 2013: Data Histopatologik. Jakarta: Yayasan Kanker Indonesia (2017).

(8) American Cancer Society. Cancer Facts and Figures 2015. Atlanta: American Cancer Society Inc, pp. 9-11 (2015).

(9) Vu, T. Claret, FX. Trastuzumab: Updated Mechanisms of Action and Resistance in Breast Cancer. Frontiers in Oncology, Vol 2, No. 62, pp.1-6 (2012). 
(10) Dittrich, A. Gautrey, H. Browell, D. Tyson-Capper. The HER2 Signaling Network in Breast Cancer-Like a Spider in its Web. J Mammary Gland Biol Neoplasia, Vol. 19, No. 3-4, pp. 253-70 (2014). DOI 10.1007/s10911-014-9329-5.

(11) Gajria, D. Chandarlapaty, S. HER2-amplified Breast Cancer: Mechanisms of Trastuzumab Resistance and Novel Targeted Therapies. Expert Rev Anticancer Ther. Vol. 11, No. 2, pp. 263-75 (2011).

(12) Pareja, F. Pines, G. Yarden, Y. The EGFR/ERBB Receptor Family. In (Wheeler DL, Yarden Y, eds) Receptor Tyrosine Kinases: Family and Subfamilies. Switzerland: Springer International Publishing, pp. 107-64 (2015).

(13) Dey, N. Leyland-Jones, B. De, P. HER2 Signaling Network in Advanced Breast Cancer: Opportunities for Combination Therapies. In (Dey N, De P, Leyland-Jones B, eds) PI3K-mTOR in Cancer and Cancer Therapy. New York: Springer Science + Business Media, pp. 231-61 (2016).

(14) Matsumoto, A. Jinno, H. Ando, T. Fujii, T. Nakamura, T. Saito, J. et al. Biological Markers of Invasive Breast Cancer. Jpn J Clin Oncol, Vol. 46, No. 2, pp. 99-105 (2016).

(15) Masoud, V. Pagès, G. Targeted Therapies in Breast Cancer: New Challenges to Fight Against Resistance. World J Clin Oncol, Vol. 8, No. 2, pp. 120-34 (2017).

(16) Martin, HL. Smith, L. Tomlinson, DC. Multidrug-resistant Breast Cancer: Current Perspectives. Breast Cancer: Targets and Therapy, Vol. 6, pp. 1-13 (2014).

(17) Shin, SJ. Gong, G. Lee, HJ. Kang, J. Bae, YK. Lee, A. et al. Positive Expression of Insulin-Like Growth Factor-1 Receptor Is Associated with a Positive Hormone Receptor Status and a Favorable Prognosis in Breast Cancer. J Breast Cancer, Vol. 17, No. 2, pp. 113-20 (2014).

(18) De Groot, S. Charehbili, A. Van Laarhoven, HWM. Mooyaart, AL. Dekker-Ensink, NG. Van de Ven, S. et al. Insulin-like Growth Factor 1 Receptor Expression and IGF1R 3129G>T Polymorphism are Associated with Response to Neoadjuvant Chemotherapy in Breast Cancer Patients: Results from the NEOZOTAC Trial (BOOG 2010-01). Breast Cancer Res, Vol. 18, No. 3, pp. 1-11 (2016).

(19) Harahap, WA. Metilasi Promoter Breast Cancer Gene 1 dan Hubungannya dengan Faktor Prognostik Karsinoma Payudara Sporadik Premenopause pada Etnis Minang. Disertasi, Universitas Andalas, Indonesia (2014).

(20) Khambri, D. Hubungan Ekspresi Androgen Receptor dengan Faktor Prognostik Karsinoma Payudara di Sumatera Barat. Disertasi, Universitas Andalas, Indonesia (2015).

(21) Tinambunan, A. Sulastri, H. Julianita, F. Bahar, E. Hubungan Ekspresi Top2A dengan Karakteristik Histopatologi dan Status Reseptor Hormon pada Karsinoma Payudara Her-2 Positif. Majalah Patologi Indonesia, Vol. 22, No. 2, pp. 31-7 (2013).

(22) Kosasih, J. Artha, IGA. Hubungan Overekspresi Topoisomerase II Alfa dengan Overekspresi Her-2/neu dan Berbagai Derajat Histologik Karsinoma Duktal Invasif Tidak Spesifik Payudara. Majalah Patologi Indonesia, Vol. 20, No. 1, pp. 6-13 (2011).

(23) Ng, CH. Pathy, NB. Taib, NA. Teh, YC. Mun, KS. Amiruddin, A. et al. Comparison of Breast Cancer in Indonesia and Malaysia-a clinicopathological Study Between Dharmais Cancer Centre Jakarta and University Malaya Medical Centre, Kuala Lumpur. Asian Pac J Cancer Prev, Vol. 12, pp. 2943-6 (2011). 
(24) Hutagalung, SB. Mulyadi, IK. Artha, IGA. Ekspresi Ki-67 dan HER-2/neu Berhubungan dengan Derajat Histopatologik Karsinoma Payudara Invasif No Special Type (NST). Majalah Patologi Indonesia, Vol. 23, No. 2, pp. 45-50 (2014).

(25) Mousavi, SM. Mohaghegghi, MA. Mousavi-Jerrahi, A. Nahvijou, A. Seddighi, Z. Burden of Breast Cancer in Iran: A Study of the Tehran Population Based Cancer Registry. Asian Pac J Cancer Prev, Vol. 7, pp. 571-4 (2006).

(26) Yip, CH. Taib, NAM. Mohamed, I. Epidemiology of Breast Cancer in Malaysia. Asian Pac J Cancer Prev, Vol. 7, pp. 369-74 (2006).

(27) Kamarlis, RK. Analisa Korelasi SOX2 dan p63 dalam Penentuan Gambaran Histopatologik Kanker Payudara Jenis Basal-like dan Non Basal-like. Disertasi, Universitas Sumatera Utara, Indonesia (2017).

(28) Devi, CRB. Tang, TS. Corbex, M. Incidence and Risk Factors for Breast Cancer Subtypes in Three Distinct South-East Asian Ethnic Groups: Chinese, Malay and Natives of Sarawak, Malaysia. Int J Cancer, Vol. 131, No. 12, pp. 2869-77 (2012).

(29) Aryandono, T. Harijadi. Soeripto. Hormone Receptor Status of Operable Breast Cancers in Indonesia: Correlation with Other Prognostic Factors and Survival. Asian Pac J Cancer Prev, Vol. 7, pp. 321-4 (2006).

(30) Jatiluhur, IM. Yantisetiasti, A. Hassan, AH. Hernowo, BS. Hubungan antara HER2/neu dan Ki-67 dengan Respon Kemoterapi Neoadjuvan pada Karsinoma Payudara Lanjut Lokal. Majalah Patologi Indonesia, Vol. 23, No. 3, pp. 32-40 (2014).

(31) Kadi, TA. Hoesin, F. Ekspresi Matrix Metalloproteinase-9 (MMP-9), HER-2/neu dan Metastasis Kelenjar Getah Bening pada Karsinoma Payudara Duktal Invasif. Majalah Patologi Indonesia, Vol. 23, No. 1, pp. 28-34 (2014).

(32) Nelson, H. Maulani, H. Farida, A. Saleh, MI. Hubungan antara Ekspresi Vascular Endothelial Growth Factor (VEGF) dengan Karakteristik Klinikopatologik Karsinoma Payudara Duktal Invasif. Majalah Patologi Indonesia, Vol. 23, No. 1, pp. 48-53 (2014).

(33) Widodo, I. Dwianingsih, EK. Triningsih, E. Utoro, T. Soeripto. Clinicopathological Features of Indonesian Breast Cancers with Different Molecular Subtypes. Asian Pac J Cancer Prev, Vol. 15, No. 15, pp. 6109-13 (2014).

(34) Aini, N. Kasno. Basuki, R. Hubungan Antara Ekspresi Protein Her-2/Neu dengan Derajat Diferensiasi Penderita Karsinoma Payudara Jenis Duktus Invasif. Jurnal Kedokteran Muhammadiyah, Vol. 2, No. 1, pp 12-5 (2015).

(35) Yerushalmi, R. Gelmon, KA. Leung, S. Gao, D. Cheang, M. Pollak, M. et al. Insulin-like Growth Factor Receptor (IGF-1R) in Breast Cancer Subtypes. Breast Cancer Res Treat, Vol. 132, No. 1, pp. 131-42 (2012).

(36) Fu, P. Ibusuki, M. Yamamoto, Y. Hayashi, M. Murakami, K. Zheng, S. et al. Insulin-like Growth Factor-1 Receptor Gene Expression is Associated with Survival in Breast Cancer: a Comprehensive Analysis of Gene Copy Number, mRNA and Protein Expression. Breast Cancer Res Treat, Vol. 130, No. 1, pp. 30717 (2011).

(37) Köstler, WJ. Hudelist, G. Rabitsch, W. Czerwenka, K. Müller, R. Singer, CF. et al. Insulin-like Growth Factor-1 Receptor (IGF-1R) Expression Does Not Predict for Resistance to Trastuzumab-based Treatment in Patients with HER-2/neu Overexpressing Metastatic Breast Cancer. J Cancer Res Clin Oncol, Vol. 132, No. 1, pp. 9-18 (2006). 
(38) Lester, SC. The Breast. In (Kumar V, Abbas AK, Aster JC, eds) Robbins and Cotran Pathologic Basis of Disease, $9^{\text {th }}$ ed. Philadelphia: Elsevier Saunders, pp. 1051-64 (2015).

(39) Kasprzak, A. Kwasniewski, W. Adamek, A. Gozdzicka-Jozefiak, A. Insulin-like Growth Factor (IGF) Axis in Cancerogenesis. Mutat Res Rev Mutat Res, Vol. 772, pp. 78-104 (2017).

(40) De Ruijter, TC. Veeck, J. de Hoon, JPJ. Van Engeland, M. Tjan-Heijnen, VC. Characteristics of Triple-negative Breast Cancer. J Cancer Res Clin Oncol, Vol. 137, No. 1, pp. 183-92 (2011). 